\title{
Sulfur Conversion of Mixed Coal and Gangue during Combustion in a CFB Boiler
}

\author{
Lizheng Zhao, Yanfei Du, Yusen Zeng, Zhizhong Kang * and Baomin Sun
}

School of Energy, Power and Mechanical Engineering, North China Electric Power University, Beijing 02206, China; lizheng_zhao@126.com (L.Z.); yanfei_du2015@126.com (Y.D.); ZengYusenZYS@163.com (Y.Z.); sbm@ncepu.edu.cn (B.S.)

* Correspondence: kzz@ncepu.edu.cn; Tel.: +86-134-8880-8739

Received: 18 December 2019; Accepted: 22 January 2020; Published: 23 January 2020

\begin{abstract}
The construction of a power plant using a $660 \mathrm{MW}_{\mathrm{e}}$ supercritical circulating fluidized bed (CFB) boiler with co-combustion of coal and gangue has been proposed in China. Therefore, this study simulated the distribution law and transformation mechanism of sulfur-containing phases using three low-calorific samples of gangue and coal mixtures under different conditions, based on the thermodynamic simulation software HSC Chemistry. The results showed that sulfur low in calorific value coal is mainly converted into gas phase $\mathrm{SO}_{2}$, solid phase alkali metal sulfate $\left(\mathrm{Na}_{2} \mathrm{SO}_{4}\right.$ and $\left.\mathrm{K}_{2} \mathrm{SO}_{4}\right)$, and alkaline earth metal sulfate $\left(\mathrm{CaSO}_{4}\right.$ and $\left.\mathrm{MgSO}_{4}\right)$ in an oxidizing atmosphere. Under a reductive atmosphere, sulfur in coal is mainly converted into gaseous $\mathrm{H}_{2} \mathrm{~S}, \mathrm{COS}$ (Carbon oxysulfide), and solid $\mathrm{FeS}_{\mathrm{x}}$. With an increase in the $\mathrm{O} / \mathrm{C}$ ratio, the distribution curve of sulfur-containing substances contracted to lower temperatures. It was established that the sulfur fixation capacity of coal ash depends on the relative amounts of basic oxides and sulfur present in it. Relevant conclusions were also verified and compared to those of the laboratory small-fluidized bed test bench and the $3 \mathrm{MW}_{\text {th }}$ CFB combustion test bench.
\end{abstract}

Keywords: circulating fluidized bed (CFB); coal and gangue co-combustion; sulfur fixation; sulfur compounds

\section{Introduction}

Approximately 30 million tons of coal gangue are produced annually in the Pingshuo area of Shanxi, China. Thus, two $660 \mathrm{MW}_{\mathrm{e}}$ supercritical circulating fluidized bed (CFB) boilers have been proposed to burn the mixture of coal and gangue [1].

Middling is coal that has an ash content between clean coal and gangue after coal washing. Its volatile content is about 10-15\% and its ash content is about 30-40\% [2]. Coal gangue is a carbonaceous rock produced by coal during the washing process. It is characterized by a large amount of $\mathrm{SiO}_{2}$ and $\mathrm{Al}_{2} \mathrm{O}_{3}$, and metal oxides such as $\mathrm{Fe}_{2} \mathrm{O}_{3}, \mathrm{CaO}$, and $\mathrm{MgO}$. The sulfur content of coal gangue is within $1-3 \%$, which is classified as medium-high sulfur coal. Its output accounts for about $10-20 \%$ of the raw coal output [3]. Generally, gangue with a calorific value higher than $1200 \mathrm{kcal}$ is used to generate electricity by blending it with a certain proportion of medium-calorific value fuel (coal slime or middling) [4]. The main feature of CFB boilers is the multiple cycles of fuel, repeated low-temperature combustion, and long combustion time, which is very suitable for burning low-calorie coal with a high sulfur content [1].

However, with the country's stricter requirements for $\mathrm{SO}_{2}$ emissions, most $\mathrm{CFB}$ units cannot meet the $\mathrm{SO}_{2}$ control requirements specified in the standard [5,6]. The existence of sulfur in coal has a great influence on the precipitation characteristics of sulfur when coal is burned in a fluidized bed. Thus, 
it is very important to study the transformation rules of sulfur in low calorific value coal in circulating fluidized beds (CFB) [7-10].

A large number of studies have shown that oxygen-enriched combustion can comprehensively treat pollutants such as $\mathrm{CO}, \mathrm{NO}_{\mathrm{x}}$, and $\mathrm{SO}_{2}$ [11], and the desulfurization efficiency after calcium injection can reach $90 \%$ [12]. Researchers have found that the combination of CFB technology and oxygen-enriched combustion can achieve the dual purpose of improving combustion efficiency and good control of pollutants, such as the FW company in the United States [13] and the Canadian Energy Technology Center [14-16]. During the combustion and circulation process, the materials in the CFB boiler experiences the alternating state of the local reducing atmosphere in the dense phase zone and the oxidizing atmosphere in the lean phase zone. Anders Lyngfelt [17] studied the decomposition characteristics of $\mathrm{CaSO}_{4}$ under different $\mathrm{CO}$ concentrations and the conversion between $\mathrm{CaS}$ and $\mathrm{CaSO}_{4}$ in an alternating atmosphere. In addition, under high temperature (above $1570 \mathrm{~K}$ ) oxidizing atmosphere, the conventional sulfur-fixing product $\mathrm{CaSO}_{4}$ cannot exist stably, due to decomposition. The calcium-based sulfur-fixing reaction begins to form a complex salt-calcium sulfoaluminate $(3 \mathrm{CaO}$ - $3 \mathrm{Al}_{2} \mathrm{O}_{3} \bullet \mathrm{CaSO}_{4}$, referred to as $\mathrm{C}_{4} \mathrm{~A}_{3} \mathrm{~S}$ ).

Relevant research also shows that furnace temperature, residence time, coal particle size, and airflow are among the factors that affect sulphur precipitation during coal combustion $[18,19]$. Moreover, bed temperature, $\mathrm{Ca} / \mathrm{S}$ ratio, limestone particle size, circulation ratio, and fluidization rate are among the factors that affect sulfur fixation [20]. By tracing the gas concentration at a combustion temperature of $1570 \mathrm{~K}$, Lyngleft [17] established oxygen consumption, volumetric CaS production, and the reductive decomposition product of $\mathrm{CaSO}_{4}$ as the main factors affecting sulfur fixation efficiency. Desulfurization is defined as the reaction between $\mathrm{CaO}$ and $\mathrm{SO}_{2}$ [21-23]. Owing to the sulfur self-fixation capacity of the mineral, an increase in oxygen concentration promotes the conversion of sulfur to sulfate instead of gaseous $\mathrm{SO}_{2}$ in coal.

At present, there are few studies on the sulfur conversion characteristics of mixed coal and gangue during co-combustion in a CFB through simulation. Therefore, this study simulated and verified the distribution rule and transformation mechanism of sulfur in experimental coal samples under different conditions, through the thermodynamic simulation software HSC Chemistry, using a small fluidized bed test bench and a $3 \mathrm{MW}_{\mathrm{th}} \mathrm{CFB}$ combustion test bed. The $\mathrm{SO}_{\mathrm{x}}$ emission characteristics and sulfur consolidation rule when burning low calorific value coal [24] are also studied. In addition, this study aims to provide references for the design of a CFB boiler for a $660 \mathrm{MW}_{\mathrm{e}}$ unit and to aid the selection of a pollutant control scheme.

\section{Materials and Methods}

\subsection{Coal Quality Analysis of Design Coal}

The design coal for the supercritical $600 \mathrm{MW}_{\mathrm{e}} \mathrm{CFB}$ boiler was middling and was combined with two kinds of gangue. Table 1 shows the chemical analysis of the gangue, middling, and the two kinds of mixed coal based on "as received basis". Sample coal I and II were, respectively, mixed from middling with gangue I and gangue II. The sulfur content of the middling and gangue was within the range of $1-3 \%$, which can be classified as medium and high-sulfur coal. The oxygen content was higher than that of the power coal used in China; hence, it was necessary to consider the experimental influence of the relative amount of $\mathrm{C}$ and $\mathrm{O}$ in the coal sample. 
Table 1. Chemical analysis of gangue and coal samples.

\begin{tabular}{cccccc}
\hline \multicolumn{5}{c}{ Elemental Analysis (\%) } \\
\hline & Gangue I & Gangue II & Middling & Sample Coal I & Sample Coal II \\
\hline $\mathrm{C}_{\mathrm{ar}}$ & 14.32 & 9.38 & 46.22 & 33.46 & 31.48 \\
$\mathrm{H}_{\mathrm{ar}}$ & 2.06 & 1.7 & 3.24 & 2.77 & 2.62 \\
$\mathrm{O}_{\mathrm{ar}}$ & 11.67 & 10.38 & 16.93 & 14.83 & 14.31 \\
$\mathrm{~N}_{\mathrm{ar}}$ & 0.54 & 0.35 & 0.89 & 0.75 & 0.67 \\
$\mathrm{~S}_{\mathrm{ar}}$ & 1.65 & 2.49 & 1.40 & 1.5 & 1.84 \\
$\mathrm{~A}_{\mathrm{ar}}$ & 63.5 & 70.3 & 25.79 & 40.87 & 43.59 \\
\hline \multicolumn{5}{c}{ Analysis of ash composition (\%) } \\
\hline & Gangue I & Gangue II & Middling & Sample coal I & Sample coal II \\
\hline $\mathrm{SiO}_{2}$ & 49.25 & 50.28 & 48.35 & 48.71 & 49.12 \\
$\mathrm{Al}_{2} \mathrm{O}_{3}$ & 37.98 & 39.25 & 36.28 & 36.96 & 37.47 \\
$\mathrm{Fe}_{2} \mathrm{O}_{3}$ & 6.90 & 4.59 & 4.64 & 5.54 & 4.62 \\
$\mathrm{CaO} \mathrm{O}$ & 1.07 & 1.27 & 1.69 & 1.44 & 1.52 \\
$\mathrm{MgO}$ & 0.16 & 0.12 & 0.95 & 0.63 & 0.62 \\
$\mathrm{TiO}_{2}$ & 2.27 & 2.31 & 1.53 & 1.83 & 1.84 \\
$\mathrm{~K}_{2} \mathrm{O}$ & 0.48 & 0.25 & 0.78 & 0.66 & 0.57 \\
$\mathrm{Na}_{2} \mathrm{O}$ & 0.32 & 0.38 & 0.42 & 0.38 & 0.40 \\
\hline
\end{tabular}

The two kinds of gangue used had nearly similar ash contents and proportions of alkaline metal oxides, while the difference of the sulfur fraction was significantly larger. Therefore, the relative proportion of alkaline oxides, such as calcium, magnesium, kalium, and sodium, in the ash and sulfur, varied greatly after they were mixed with the middling. In the thermodynamic simulation, we thought that the contact was sufficient, the reaction time was long enough, and the reaction was sufficient. We could choose the reaction and equilibrium phase components that occurred in different situations according to the simulation conditions. Therefore, the molar ratios of the four alkaline oxides in relation to sulfur in coal were as follows:

$$
\begin{aligned}
& \text { Calcium - sulfur mol ratio }=0.005714 \times \frac{\mathrm{A}_{\mathrm{ar}} \times \mathrm{CaO}}{\mathrm{S}}, \\
& \text { Magnesium - sulfur mol ratio }=0.008 \times \frac{\mathrm{A}_{\mathrm{ar}} \times \mathrm{MgO}}{\mathrm{S}}, \\
& \text { Kalium - sulfur mol ratio }=0.00681 \times \frac{\mathrm{A}_{\mathrm{ar}} \times \mathrm{K}_{2} \mathrm{O}}{\mathrm{S}}, \\
& \text { Sodium - sulfur mol ratio }=0.010323 \times \frac{\mathrm{A}_{\mathrm{ar}} \times \mathrm{Na}_{2} \mathrm{O}}{\mathrm{S}},
\end{aligned}
$$

where $\mathrm{A}_{\mathrm{ar}}$ is the ash content of the coal sample, $\mathrm{CaO}, \mathrm{MgO}, \mathrm{K}_{2} \mathrm{O}$, and $\mathrm{Na}_{2} \mathrm{O}$ are the percentages of the corresponding substances in the ash, respectively, and $\mathrm{S}$ is the total sulfur of the coal sample. The alkaline-oxide/S ratio is the sum of the molar ratios of the basic oxides of calcium, magnesium, kalium, and sodium to sulfur. The results of these equations are shown in Table 2.

Table 2. Alkaline oxide to sulfur ratio.

\begin{tabular}{cccc}
\hline & Middling & Sample Coal I & Sample Coal II \\
\hline $\mathrm{Ca} / \mathrm{S}$ & 0.178 & 0.224 & 0.206 \\
$\mathrm{Mg} / \mathrm{S}$ & 0.140 & 0.138 & 0.117 \\
$\mathrm{~K} / \mathrm{S}$ & 0.098 & 0.123 & 0.092 \\
$\mathrm{Na} / \mathrm{S}$ & 0.080 & 0.107 & 0.099 \\
Alkaline-oxide/S & 0.496 & 0.592 & 0.515 \\
\hline
\end{tabular}




\subsection{Thermodynamic Equilibrium Calculation of Sulfur-Containing Substances}

The bed material in the CFB boiler was divided into a dense phase region and a diluted phase region in the lower and upper regions, respectively. The dense phase region was entirely in a reducing atmosphere, while the diluted phase region was in an oxidizing atmosphere. These difference in the atmosphere resulted in different mechanisms of sulfur precipitation and different sulfur-containing substances [25].

Using the HSC Chemistry thermodynamic database, the types of reactants, number of moles, and stable phases that might have occurred during the reaction were given as inputs to obtain the equilibrium phase composition curve under certain temperatures and pressures. This software was mainly based on the Gibbs minimum energy principle and obtained the equilibrium composition of the system response under the premise of meeting the mass conservation. The distributions of sulfur-containing substances with contents greater than $10^{-5}$ mol were investigated in the material system after calculation.

\subsubsection{Mechanism of Sulfur Evolution during Coal Combustion}

Inorganic sulfur [26] in fuel comes from various sulfur compounds in the mineral. Under an oxidizing atmosphere, pyrite sulfur can be directly converted into $\mathrm{SO}_{2}$.

$$
4 \mathrm{FeS}_{2}+11 \mathrm{O}_{2}=2 \mathrm{Fe}_{2} \mathrm{O}_{3}+8 \mathrm{SO}_{2}
$$

Under a reducing atmosphere, $\mathrm{FeS}_{2}$ will undergo decomposition reaction:

$$
\begin{gathered}
2 \mathrm{FeS}_{2}=2 \mathrm{FeS}+\mathrm{S}_{2} \\
2 \mathrm{FeS}_{2}+\mathrm{H}_{2}=\mathrm{FeS}+\mathrm{H}_{2} \mathrm{~S} \\
\mathrm{FeS}_{2}+\mathrm{CO}=\mathrm{FeS}+\mathrm{COS}
\end{gathered}
$$

Organic sulfur [27] components in coal combustion are more complex with their main forms of thiol R-SH, thioether R-S-R, thiophene-containing aromatic system, thioxanthone, and disulfide RSSR. In an oxidizing atmosphere, they are all oxidized to $\mathrm{SO}_{2}$ :

$$
\begin{gathered}
\mathrm{RHS}+\mathrm{O}_{2}=\mathrm{RS}+\mathrm{HO}_{2} \\
\mathrm{RS}+\mathrm{O}_{2}=\mathrm{R}+\mathrm{SO}_{2}
\end{gathered}
$$

In a reductive atmosphere of aerobic combustion, organic sulfur is converted to $\mathrm{H}_{2} \mathrm{~S}$ and COS. The elemental sulfur [28] in the coal enters the sulfide flame in the form of sulfur vapor when heated:

$$
\begin{gathered}
\mathrm{S}_{\mathrm{S}}=\mathrm{S}_{7}+\mathrm{S} \\
\mathrm{S}+\mathrm{O}_{2}=\mathrm{SO}+\mathrm{O} \\
\mathrm{S}_{\mathrm{S}}+\mathrm{O}=\mathrm{SO}+\mathrm{S}_{6}+\mathrm{S}
\end{gathered}
$$

The following reactions occur when $\mathrm{SO}$ encounters oxygen:

$$
\begin{gathered}
\mathrm{SO}+\mathrm{O}_{2}=\mathrm{SO}_{2}+\mathrm{O} \\
\mathrm{SO}+\mathrm{O}=\mathrm{SO}_{2}
\end{gathered}
$$

\subsubsection{Model Simplification and Simulation of Coal}

During simulation, coal was simplified as a combination of organic elements $(\mathrm{C}, \mathrm{H}, \mathrm{O}, \mathrm{N}$, and $\mathrm{S})$ and inorganic minerals [29]. The simulated pressure was set to $0.1 \mathrm{MPa}$, which was close to the furnace pressure when the CFB boiler was running. The simulated temperature range was selected from 700 to 
$1600 \mathrm{~K}$, including the CFB operation temperature range of 1100 to $1300 \mathrm{~K}$, and the excess air ratio was 1.2. For convenience during calculation, the initial total amount of sulfur was set to $1 \mathrm{~mol}$, and those of other substances were calculated according to their respective mass percentage in coal, as shown in Table 3. After simulation, the corresponding $\mathrm{SO}_{2}$ release value $\sigma$ and the rate of solid sulfur $\eta=1-\sigma$ were obtained from the three coal samples under $1270 \mathrm{~K}$. Table 4 shows the calculation results.

Table 3. Input conditions for thermodynamic simulation.

\begin{tabular}{cccc}
\hline Component (mol) & Middling & Sample Coal I & Sample Coal II \\
\hline $\mathrm{C}$ & 176.08 & 118.97 & 91.46 \\
$\mathrm{H}$ & 74.06 & 59.05 & 45.73 \\
$\mathrm{O}$ & 24.19 & 19.79 & 15.59 \\
$\mathrm{~N}$ & 2.91 & 2.29 & 1.69 \\
$\mathrm{~S}$ & 1 & 1 & 1 \\
$\mathrm{SiO}_{2}$ & 9.50 & 14.16 & 12.44 \\
$\mathrm{Al}_{2} \mathrm{O}_{3}$ & 4.19 & 6.32 & 5.58 \\
$\mathrm{Fe}_{2} \mathrm{O}_{3}$ & 0.34 & 0.60 & 0.44 \\
$\mathrm{CaO}$ & 0.36 & 0.45 & 0.41 \\
$\mathrm{MgO}$ & 0.28 & 0.28 & 0.23 \\
$\mathrm{TiO}_{2}$ & 0.23 & 0.40 & 0.35 \\
$\mathrm{~K}_{2} \mathrm{O}$ & 0.10 & 0.12 & 0.09 \\
$\mathrm{Na}_{2} \mathrm{O}$ & 0.08 & 0.11 & 0.10 \\
\hline
\end{tabular}

Table 4. Sulfur fixation rate of simulation results.

\begin{tabular}{cccc}
\hline & Middling & Sample Coal I & Sample Coal II \\
\hline Total sulfur $(\mathrm{mol})$ & 1 & 1 & 1 \\
$\mathrm{SO}_{2}$ released $(\mathrm{mol})$ & 0.69 & 0.61 & 0.64 \\
Sulfur fixation rate $(\%)$ & 31 & 39 & 36 \\
\hline
\end{tabular}

\subsection{Experimental Design on $\mathrm{SO}_{2}$ Emission and Fixation Characteristics}

A small, fluidized bed test bench was designed in the experiment, as shown in Figure 1. This test bench mainly included a reactor body, heating furnace, and flue gas analyzer (Testo350). To simulate the air composition, the high-purity gas $\mathrm{O}_{2}$ and $\mathrm{N}_{2}$ flow ratio was set to 1:4, with a total flow rate of $1.18 \mathrm{~L} / \mathrm{min}$. The reactor was made of quartz glass with a porous medium placed $25 \mathrm{~cm}$ from the lower edge of the reactor to simulate the air distribution plate. The furnace reaction temperature was set to $1270 \mathrm{~K}$, with a thermal insulation layer to maintain the reactor temperature.

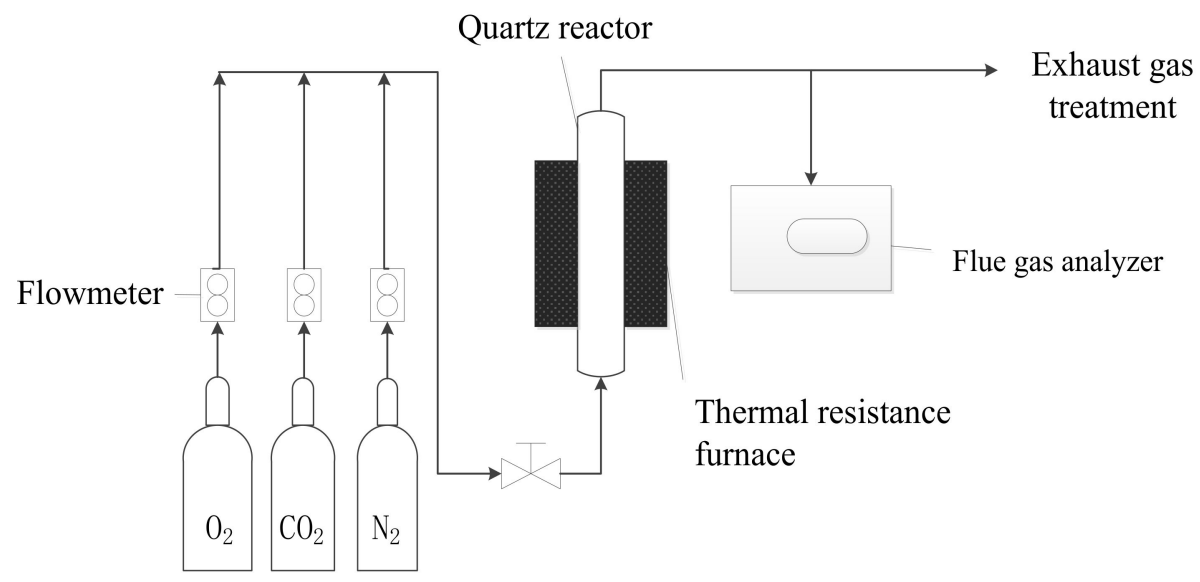

Figure 1. Schematic diagram of the small fluidized bed experimental bench. 
The bed material contained experimental coal samples $(100 \mathrm{mg})$ and sufficient quartz sand $\left(0.1-2 \mathrm{~mm}, 1000 \mathrm{~kg} / \mathrm{m}^{3}\right)$. The $\mathrm{SO}_{2}$ concentration (ppm) was recorded by the flue gas analyzer with a constant pump flowrate of $1 \mathrm{~L} / \mathrm{min}$, recording intervals of $1 \mathrm{~s}$, and recording $\mathrm{SO}_{2}$ concentrations of less than $10 \mathrm{ppm}$.

\subsection{Experimental Study of Sulfur Conversion Process Based on $3 M W_{\text {th }}$ Test Bench}

Most domestic and foreign experiments on sulfur precipitation during coal combustion could not effectively simulate the sulfur conversion process in a fluidized bed. Some researchers carried out dynamic sulfur fixation experiments with limitations, due to the short reaction time. Thus, this study performed the experiment on the largest CFB test bench in China, as shown in Figure 2.

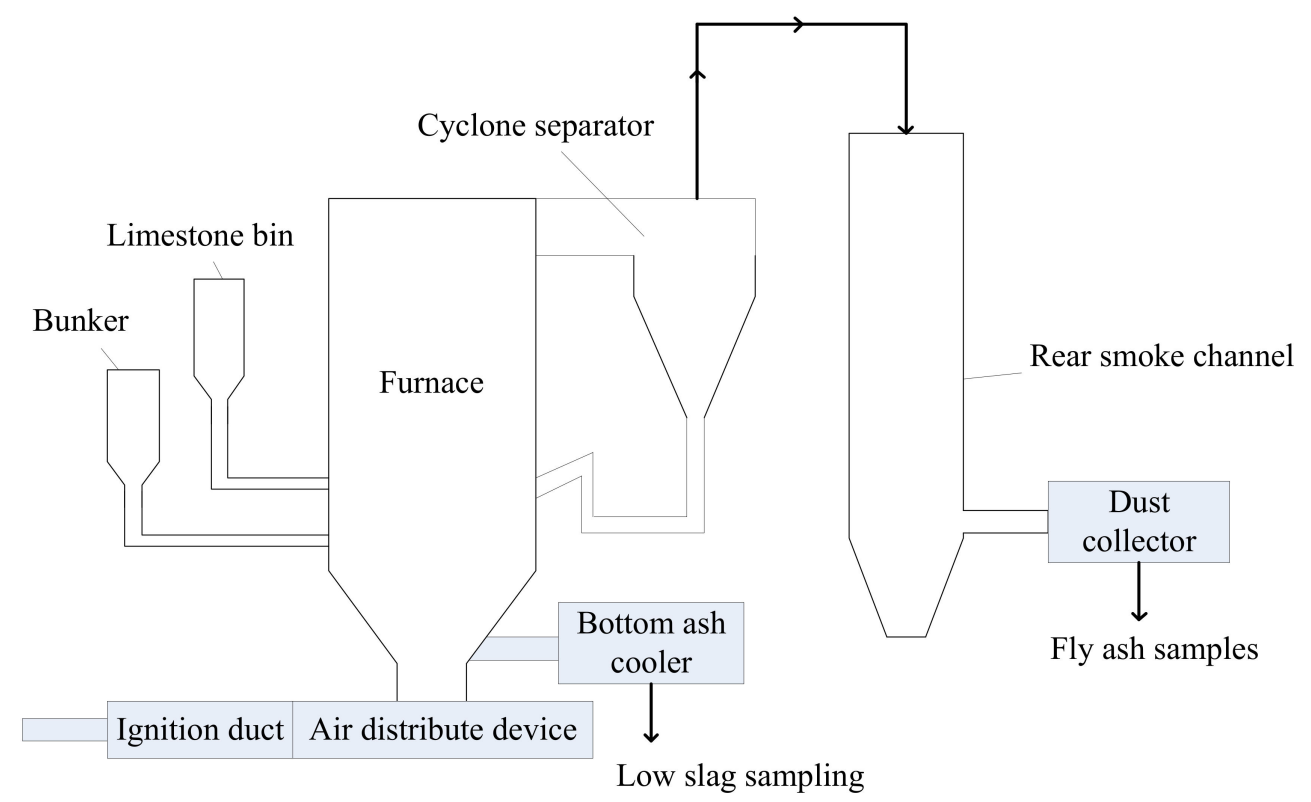

Figure 2. Flowchart of the $3 \mathrm{MW}_{\text {th }} \mathrm{CFB}$ combustion test bed.

This test bench had a $24.6 \mathrm{~m}$ high hearth and a $3 \mathrm{MW}_{\text {th }}$ rated power equipped with complete milling, air supply, circulating water, air induction, and dust removal system.

With sample coal II as an example, the amount of $\mathrm{CaO}$ and porous media in its coal ash resulted in its ability to remove and adsorb the $\mathrm{SO}_{2}$ generated from coal combustion [30-32]. A portion of the sulfur in coal existed as highly stable, such as sulfate, which could not be decomposed at the combustion temperature of the CFB. Therefore, its actual emission concentration was lower than that of the total emission concentration calculated using the total sulfur. The calcium-sulfur molar ratio Ks of coal can be defined as:

$$
\mathrm{Ks} \text {, self }=0.00571 \times \frac{\mathrm{A}_{\mathrm{arCaO}}}{\mathrm{S}_{\mathrm{ar}}}
$$

where $\mathrm{CaO}$ is the mass percentage of $\mathrm{CaO}$ in coal ash. The calcium-sulfur molar ratio $(\mathrm{Ca} / \mathrm{S})$ of the limestone added in the test is defined as the molar ratio of the total sulfur content in the limestone and in coal. The desulfurization efficiency after adding limestone is the total desulfurization efficiency of the CFB boiler including its self-desulfurization efficiency which is:

$$
\eta_{\mathrm{s}}=100-0.005 \mathrm{SO}_{2} \times \frac{\mathrm{V}_{\mathrm{gy}}}{\mathrm{S}_{\mathrm{ar}}}
$$

where $\mathrm{SO}_{2}$ is the $\mathrm{SO}_{2}$ concentration converted to $6 \% \mathrm{O}_{2}$ dry flue gas; $\mathrm{V}_{\mathrm{gy}}$ is the dry flue gas volume of $1 \mathrm{~kg}$ of coal with an excess air coefficient of $1.4\left(6 \% \mathrm{O}_{2}\right)$. 


\section{Results \& Discussion}

\subsection{Calculation of Oxidizing Atmosphere}

\subsubsection{Distribution and Transformation of Sulfur-Containing Phases}

Figure 3 shows the distribution of sulfur-containing substances at different temperatures for the three coal samples in an oxidizing atmosphere with an excess air ratio of 1.2. The solid phase is mainly composed of $\mathrm{CaSO}_{4}, \mathrm{MgSO}_{4}, \mathrm{~K}_{2} \mathrm{SO}_{4}$, and $\mathrm{Na}_{2} \mathrm{SO}_{4}$, and the gas phase has minimal $\mathrm{SO}_{2}$ and $\mathrm{SO}_{3}$. Most of the sulfur in coal is fixed by alkaline metal oxides such as $\mathrm{CaSO}_{4}$ and $\mathrm{MgSO}_{4}$ at low temperatures and is re-released as $\mathrm{SO}_{2}$ when the temperature exceeds $800 \mathrm{~K}$. When the temperature is less than $800 \mathrm{~K}$, a portion of $\mathrm{KAl}\left(\mathrm{SO}_{4}\right)_{2}$ and $\mathrm{SO}_{3}$ is generated. The reactions are as follows:

$$
\begin{gathered}
2 \mathrm{CaSO}_{4} \rightarrow 2 \mathrm{SO}_{2}+\mathrm{O}_{2}+2 \mathrm{CaO} \\
2 \mathrm{MgSO}_{4} \rightarrow 2 \mathrm{SO}_{2}+\mathrm{O}_{2}+2 \mathrm{MgO} \\
\mathrm{CaO}+\mathrm{SiO}_{2} \rightarrow \mathrm{CaSiO}_{3} \\
\mathrm{MgO}+\mathrm{Al}_{2} \mathrm{O}_{3} \rightarrow \mathrm{MgO} \cdot \mathrm{Al}_{2} \mathrm{O}_{3}
\end{gathered}
$$

$\mathrm{SO}_{3}$ at low temperatures is more stable than that of $\mathrm{SO}_{2}$. When $\mathrm{SO}_{3}$ starts to increase gradually, the order of its peak content is as follows: Middling, sample coal II, and then sample coal I. This sequence is opposite to that of the peak content of alkaline oxide in Table 2. Therefore, in lower temperatures, $\mathrm{SO}_{3}$ content is mainly restricted by alkaline oxide.

\subsubsection{Effect of Calcium to Sulfur Ratio on Sulfur Fixation}

During the operation of the CFB boiler, limestone serves as the main desulfurizer [33-35]. Improving the desulfurization efficiency can not only save a significant amount of the desulfurization cost, but can also reduce the pressure of the secondary desulfurization in the tail.

For example, with regard to sample coal I, the temperature range of 900 to $1300 \mathrm{~K}$ is chosen, and the excess air ratio is 1.2. Figures 4-6 show the relationship between the equilibrium yield of $\mathrm{SO}_{2}$, $\mathrm{CaSO}_{4}$, and $\mathrm{CaSiO}_{3}$, and the $\mathrm{Ca} / \mathrm{S}$ ratio, respectively (the $\mathrm{Ca} / \mathrm{S}$ ratio here excludes the $\mathrm{CaO}$ in the coal sample itself). Increasing the $\mathrm{Ca} / \mathrm{S}$ ratio to values less than 0.6 resulted in a rapid decrease of the $\mathrm{SO}_{2}$ content, rapid increase of $\mathrm{CaSO}_{4}$, and a relatively slow increase of $\mathrm{CaSiO}_{3}$. These indicate that the calcium-based sulfur fixation reaction mainly occurred as a reversible reaction:

$$
\begin{gathered}
\mathrm{SO}_{2}+\mathrm{CaO} \leftrightharpoons \mathrm{CaSO}_{3} \\
2 \mathrm{CaSO}_{3}+\mathrm{O}_{2} \leftrightharpoons 2 \mathrm{CaSO}_{4}
\end{gathered}
$$

As $\mathrm{CaCO}_{3}$ increases, the reaction equilibrium increases causing more immobilization of $\mathrm{SO}_{2}$.

The $\mathrm{CaO} / \mathrm{S}$ ratio in sample coal $\mathrm{I}$ is 0.449 , as shown in Table 4 . When the $\mathrm{Ca} / \mathrm{S}$ ratio is 0.6 , the total $\mathrm{Ca}$ and $\mathrm{S}$ are approximately equal to the stoichiometric ratio. The majority of the $\mathrm{SO}_{2}$ is fixed to sulfate by the sulfur fixation of alkaline oxide. Excess $\mathrm{CaCO}_{3}$ decomposed into $\mathrm{CaO}$, which reacted with $\mathrm{SiO}_{2}$ in the solid phase to form a more stable $\mathrm{CaSiO}_{3}$. The reaction of calcium-based sulfur fixation is exothermic. As the temperature increases, the reaction moves to the reverse reaction direction, which leads to the decomposition of $\mathrm{CaSO}_{4}$. Hence, the effect the $\mathrm{Ca} / \mathrm{S}$ ratio in sulfur fixation becomes less evident as the temperature is increased. 


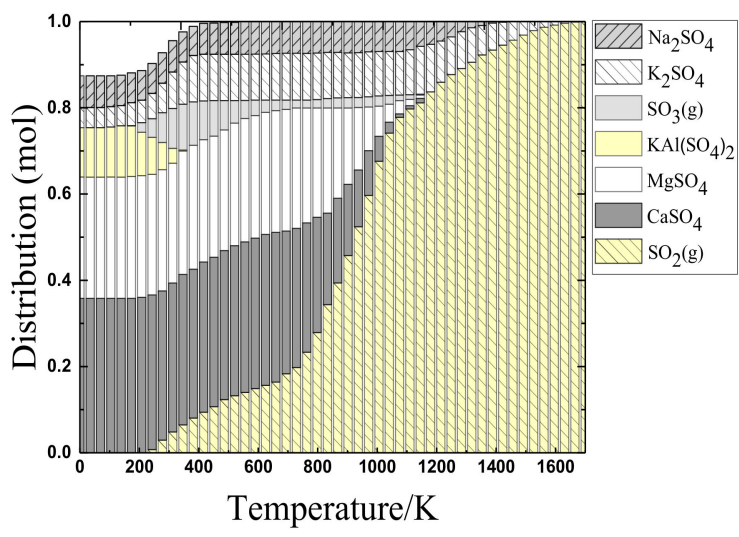

(a) Middling

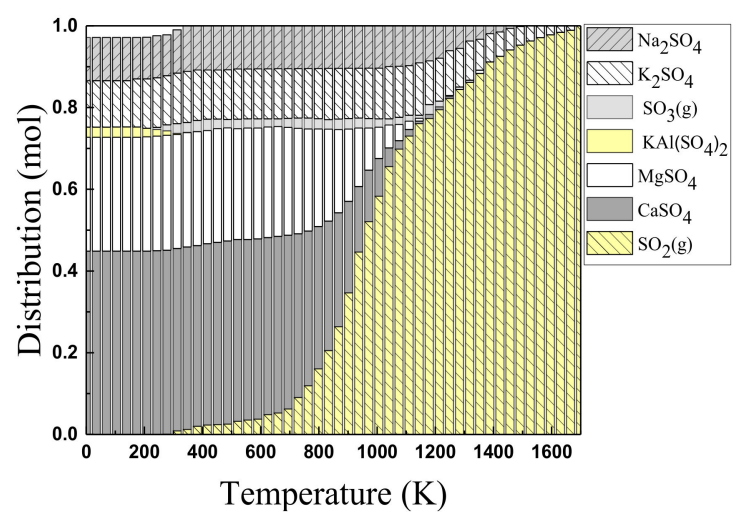

(b) Sample coal I

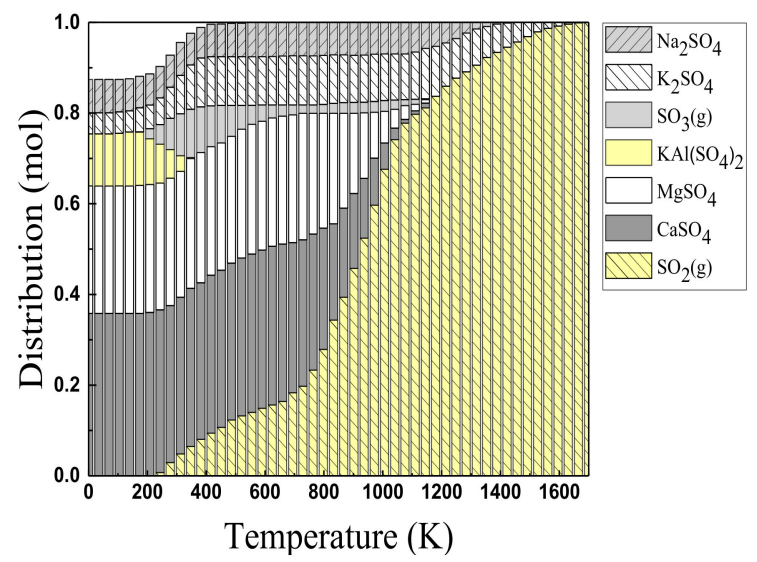

(c) Sample coal II

Figure 3. Distribution of sulfur-containing substances at different temperatures in an oxidizing atmosphere with an excess air ratio of 1.2.

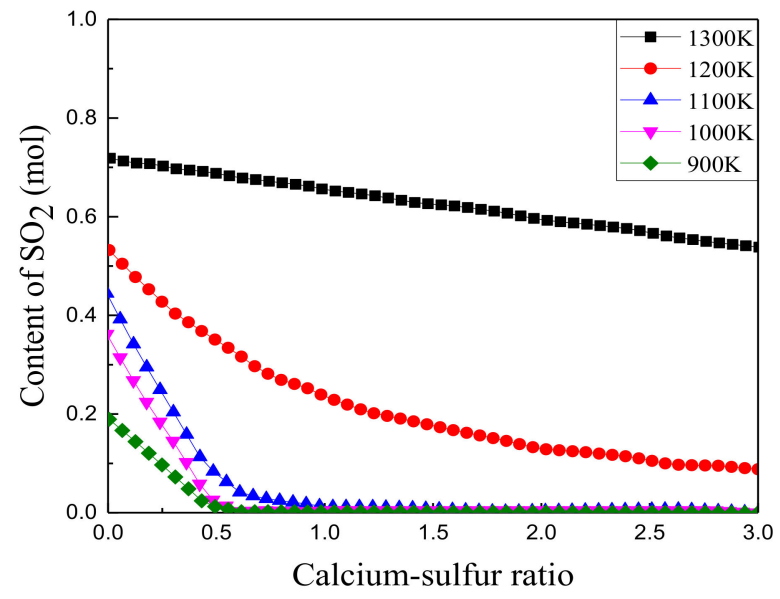

Figure 4. Balanced content of sulfur dioxide. 


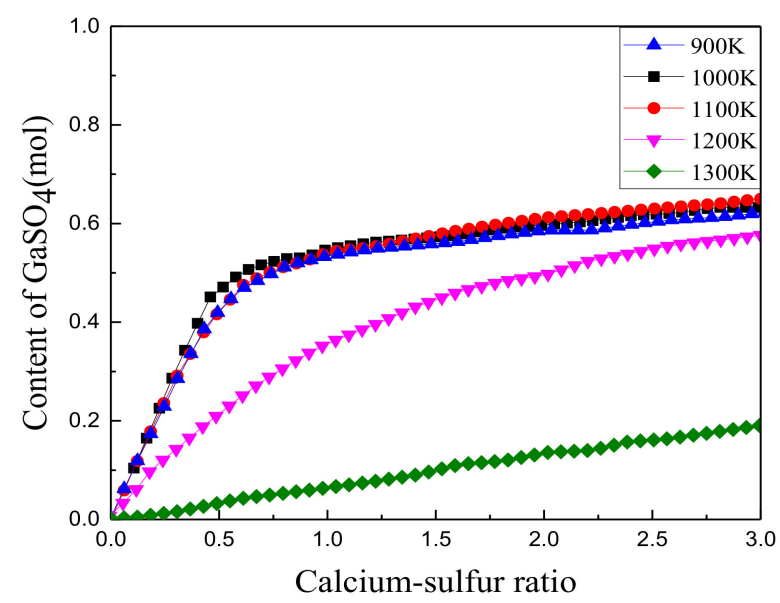

Figure 5. Balanced content of $\mathrm{CaSO}_{4}$.

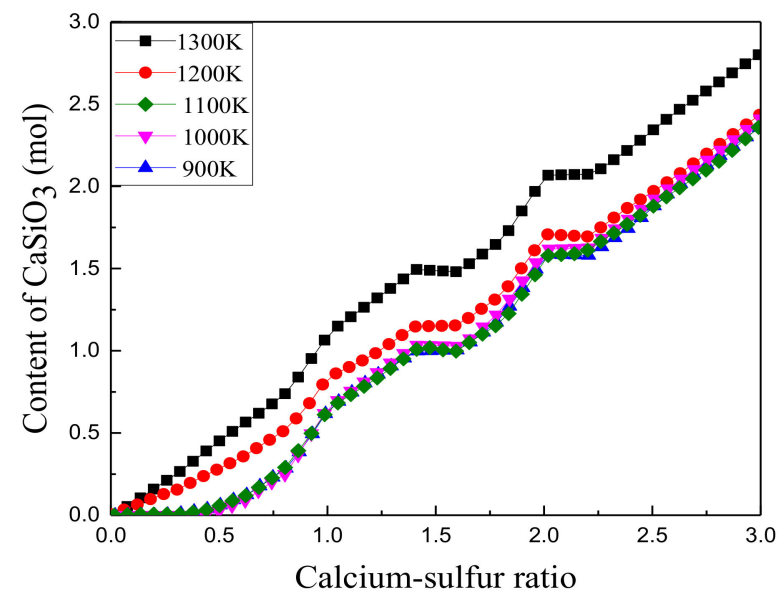

Figure 6. Balanced content of $\mathrm{CaSiO}_{3}$.

3.2. Calculation of Reducing Atmosphere

\subsubsection{Distribution of Sulfur-Containing Phases}

Figure $7 \mathrm{a}-\mathrm{c}$ show the distribution of sulfur-containing substances of the three coal samples in a strong reducing atmosphere with an excess air coefficient of 0.4 .

In the range of $800 \mathrm{~K}$ to $1000 \mathrm{~K}$, most gaseous sulfur exists in the form of $\mathrm{H}_{2} \mathrm{~S}$, with a small part existing in the form of COS. However, the composition of the solid phase sulfur-containing compound is scarce. When the temperature exceeds $1000 \mathrm{~K}$, iron sulfides, $\mathrm{Fe}_{0.877} \mathrm{~S}$ and $\mathrm{FeS}$, are the main solid phase sulfur compounds.

The distribution curve of $\mathrm{H}_{2} \mathrm{~S}$ with respect to temperature is characterized by double peaks and a single valley. When the temperature is less than $950 \mathrm{~K}$, the precipitation rate of $\mathrm{H}_{2} \mathrm{~S}$ is almost $80 \%$ or more. After the temperature exceeds $950 \mathrm{~K}$, the equilibrium content of $\mathrm{H}_{2} \mathrm{~S}$ sharply drops, thereby rapidly reaching the valley value. The higher $\mathrm{Fe}_{2} \mathrm{O}_{3}$ contents in the coal sample resulted in smaller valley values. 


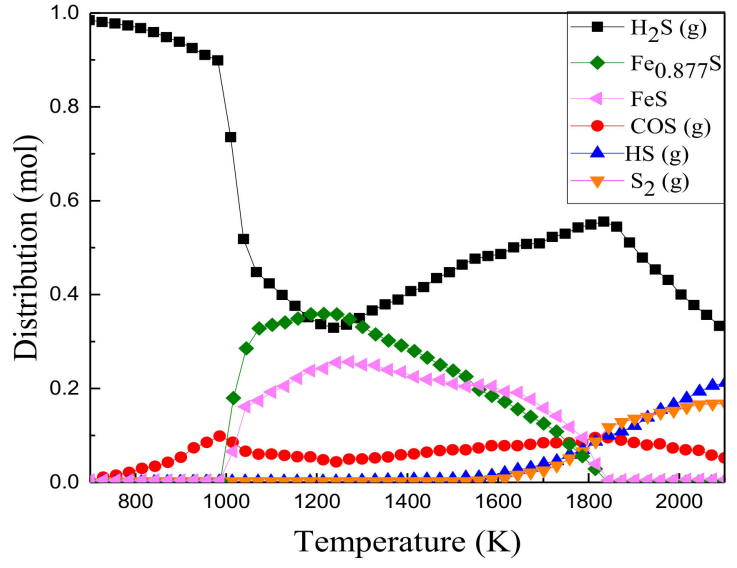

(a) Middling

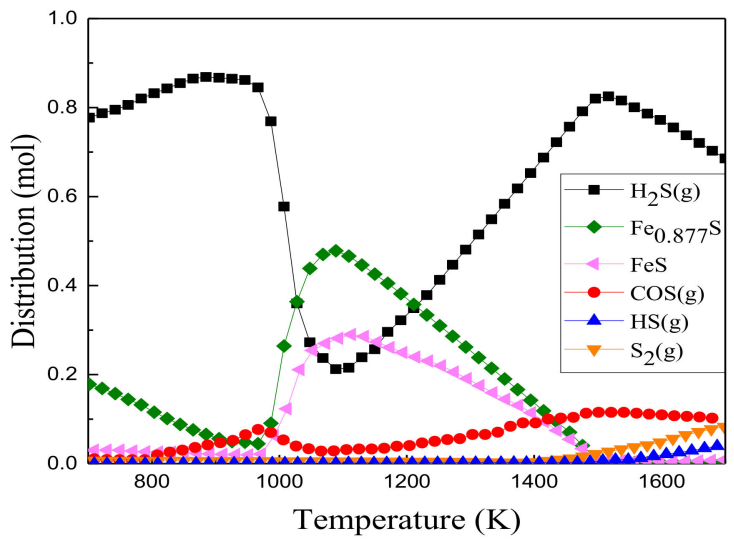

(b) Sample coal I

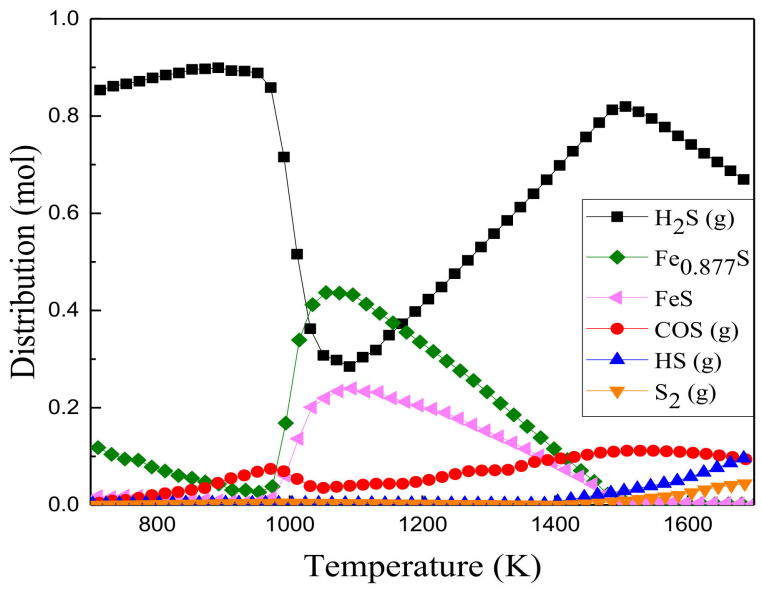

(c) Sample coal II

Figure 7. Distribution of sulfur-containing substances in a strong reducing atmosphere with an excess air coefficient of 0.4 .

For COS gas, the equilibrium content curve exhibited a bimodal characteristic with the peak temperature substantially consisting of the $\mathrm{H}_{2} \mathrm{~S}$ gas. Under a strong reducing atmosphere of more than $1400 \mathrm{~K}, \mathrm{H}_{2} \mathrm{~S}$ decomposed to produce a large amount of $\mathrm{H}_{2}$. The reaction occurred as follows:

$$
\begin{aligned}
& 2 \mathrm{H}_{2} \mathrm{~S} \leftrightharpoons 2 \mathrm{HS}+\mathrm{H}_{2} \\
& 2 \mathrm{H}_{2} \mathrm{~S} \leftrightharpoons \mathrm{S}_{2}+2 \mathrm{H}_{2}
\end{aligned}
$$

In the temperature range of $800 \mathrm{~K}$ to $1000 \mathrm{~K}$, the gas phase sulfur compounds of the middling and sample coals are mainly $\mathrm{H}_{2} \mathrm{~S}$, with small amounts of COS. No solid phase sulfur compounds are evident in the middling. In contrast, the coal blend samples show a small amount of solid phase sulfur compounds, mainly composed of $\mathrm{Fe}_{0.877} \mathrm{~S}$ and $\mathrm{FeS}$, which gradually decreases with increasing temperature.

\subsubsection{Effect of Iron Oxides}

Under an oxidizing atmosphere, iron oxide does not participate in the reaction. Under a reducing atmosphere, the sulfur content of the solid phase is mainly iron sulfide. The $\mathrm{Fe}_{2} \mathrm{O}_{3}$ content of coal ash directly influences the release of $\mathrm{H}_{2} \mathrm{~S}$.

Using sample coal I as an example, the $\mathrm{H}_{2} \mathrm{~S}$ equilibrium contents under different iron/sulfur ratios are simulated, as shown in Figure 8. When the iron/sulfur ratio is 0.1 , Fe does not affect the 
sulfur-fixing. As the iron/sulfur ratio increases, the relationship between $\mathrm{H}_{2} \mathrm{~S}$ and temperature shows the characteristics of double peaks and single valleys. In the low temperature section, the peak is visible at approximately $900 \mathrm{~K}$. Following this, the $\mathrm{H}_{2} \mathrm{~S}$ rate decreases as the iron-sulfur ratio increases. The valley is visible around $1100 \mathrm{~K}$. In the high temperature section, the "peak" moves toward higher temperatures as the iron/sulfur ratio increases. This is attributed to the increased content of iron sulfide as the iron/sulfur ratio increases, where $\mathrm{FeS}_{\mathrm{x}}$ is converted into $\mathrm{H}_{2} \mathrm{~S}$ in the endothermic reaction:

$$
\mathrm{FeS}_{\mathrm{x}}+\mathrm{H}_{2} \mathrm{O} \rightarrow \mathrm{H}_{2} \mathrm{~S}+\mathrm{FeO}+\mathrm{Fe}_{2} \mathrm{O}_{3}
$$

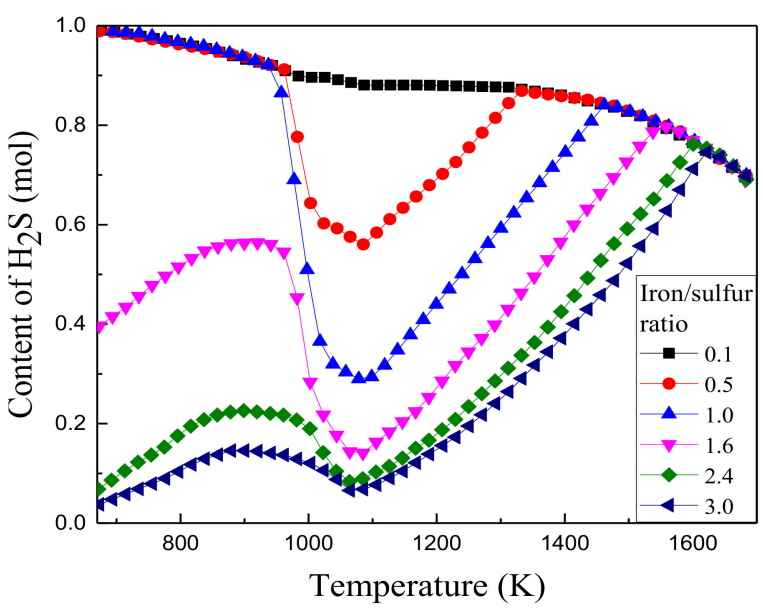

Figure 8. Relationship between $\mathrm{H}_{2} \mathrm{~S}$ content and temperature under different iron/sulfur ratio.

\subsubsection{Effect of $\mathrm{O} / \mathrm{C}$}

As shown in Figure 7, the $\mathrm{H}_{2} \mathrm{~S}$ release curve reached the peaks at different temperatures in the high-temperature section. Combined with Table 4, C, H, and O, which are affected by the reduction ability of the atmosphere [36-38], are very different between the middling and two-coal samples. By changing the initial input of these elements, thermodynamic simulation can eliminate the influence of $\mathrm{H}$. The ratio of the total $\mathrm{O}$ moles in coal and the $\mathrm{O}$ moles in air $\left(\mathrm{O}_{2}\right)$ to the $\mathrm{C}$ moles in coal is defined as the $\mathrm{O} / \mathrm{C}$ ratio. When the excess air ratio is 0.4 , the $\mathrm{O} / \mathrm{C}$ ratio of the three coal samples is calculated, as shown in Table 5.

Table 5. O/C ratio of coal samples.

\begin{tabular}{cccccc}
\hline & Unit & Middling & Sample Coal I & Sample Coal II & Corrected Value of Middling \\
\hline Original C & mol & 176.08 & 118.97 & 91.46 & 176.08 \\
Original O & mol & 24.19 & 19.79 & 15.59 & 30.19 \\
Oxygen in air & mol & 76.16 & 52.14 & 40.17 & 76.16 \\
O/C ratio & 1 & 1.002 & 1.043 & 1.049 & 1.037 \\
\hline
\end{tabular}

The $\mathrm{O} / \mathrm{C}$ ratio of the middling is significantly smaller than that of the two mixed coals. The self-contained $\mathrm{O}$ atom in the middling is increased by $6 \mathrm{~mol}$ to achieve an $\mathrm{O} / \mathrm{C}$ ratio nearly similar to that of the coal samples. The input of the remaining substances is unchanged. A thermodynamic simulation is performed to obtain a sulfur-containing phase distribution map, as shown in Figure 9. In comparison to Figure $7 \mathrm{~b}, \mathrm{c}$, the peak of the high-temperature section of the corrected curve is consistent with that of the $\mathrm{H}_{2} \mathrm{~S}$ release curve of the sample coals. This proves the aforementioned conjecture in regards to the effect of reducing the atmosphere intensity to achieve the peak of the $\mathrm{H}_{2} \mathrm{~S}$ release curve. Hence, the $\mathrm{O} / \mathrm{C}$ ratio is a more accurate characterization of the effect of the reducing atmosphere.

Using sample coal II as an example, Figure 10 shows the distribution of sulfur and solid phase sulfur at different $\mathrm{O} / \mathrm{C}$ ratios. As the $\mathrm{O} / \mathrm{C}$ ratio increases, the effect of the reducing atmosphere is weakened and the distribution curves of the sulfur-containing substance moves toward the lower temperatures. 


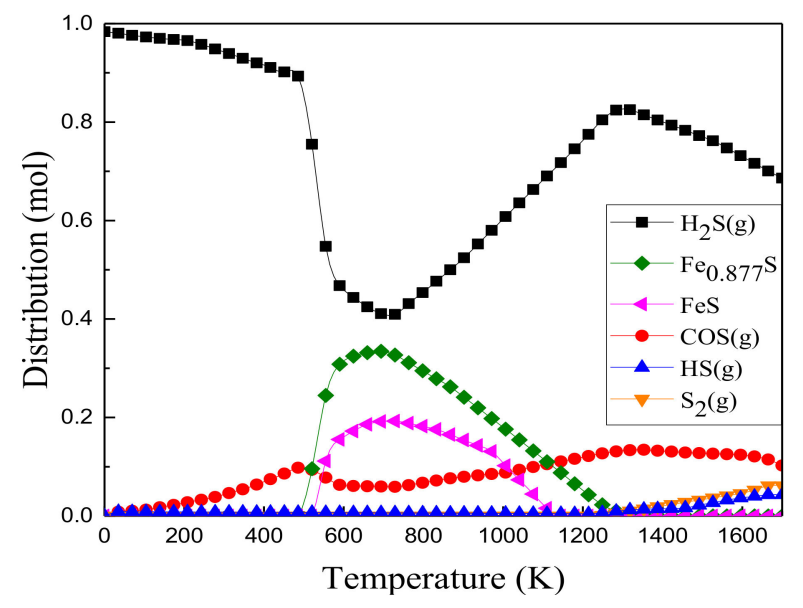

Figure 9. The corrected $\mathrm{O} / \mathrm{C}$ ratio of the middling.

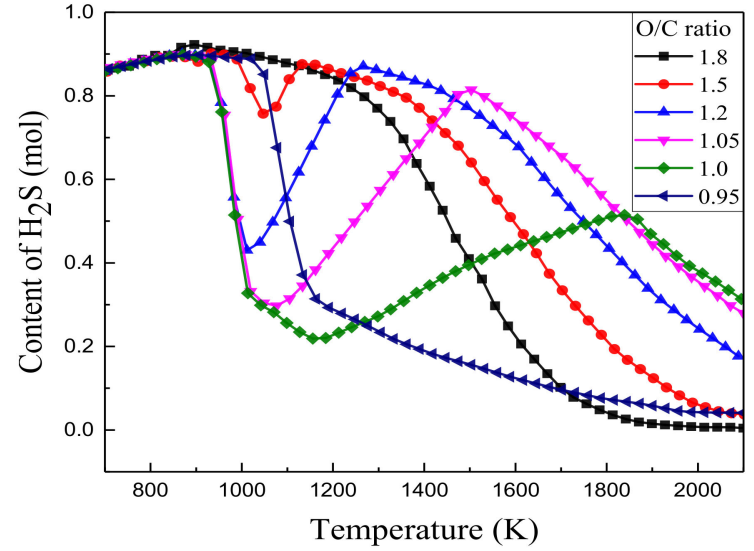

(a) $\mathrm{H}_{2} \mathrm{~S}$

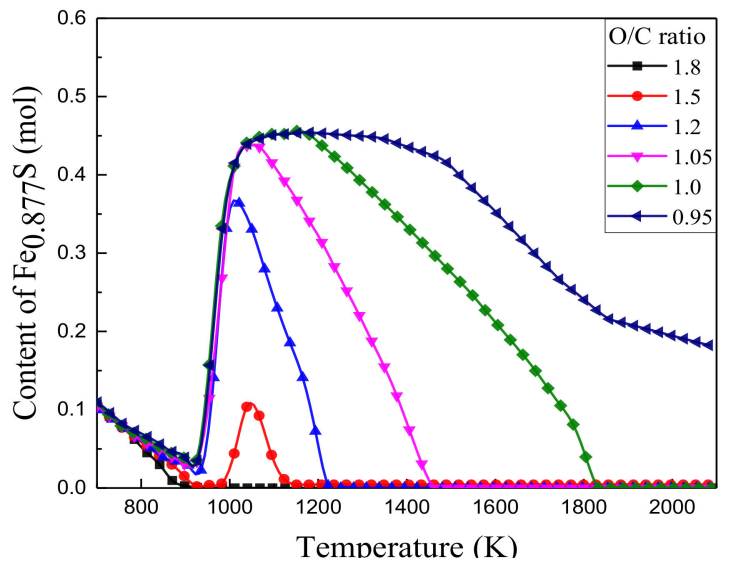

(c) $\mathrm{Fe}_{0.877 \mathrm{~S}}$

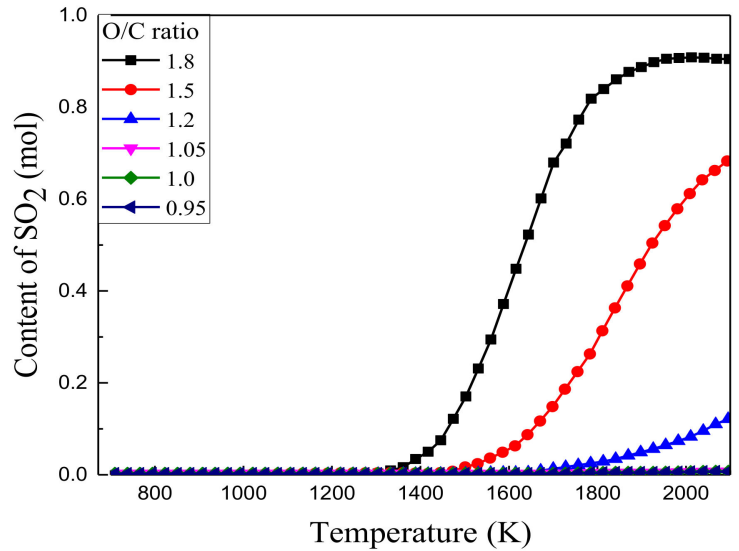

(b) $\mathrm{SO}_{2}$

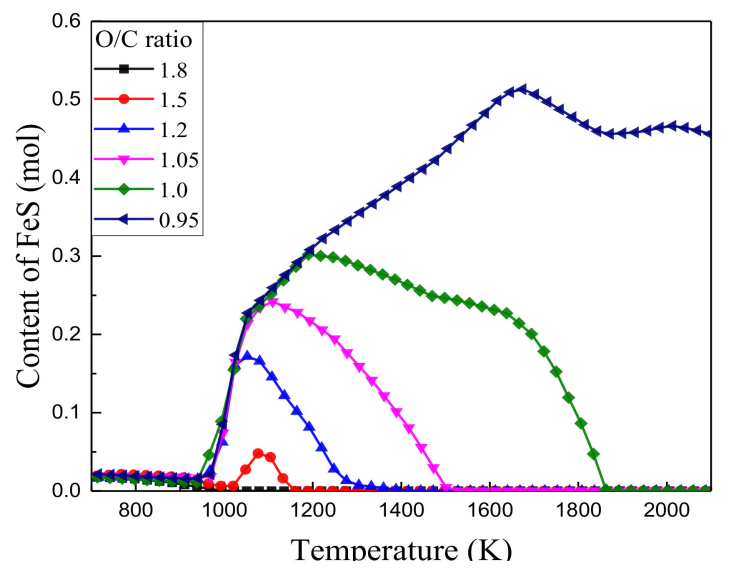

(d) $\mathrm{FeS}$

Figure 10. Distribution of sulfur-containing substances under different $\mathrm{O} / \mathrm{C}$ ratio.

From Figure $10 \mathrm{a}, \mathrm{c}, \mathrm{d}$, when the $\mathrm{O} / \mathrm{C}$ ratio is less than 1 , the peak of the $\mathrm{H}_{2} \mathrm{~S}$ curve in the high-temperature section did not exist and the iron sulfides could not decay to zero. At the $\mathrm{O} / \mathrm{C}$ ratios from 1 to 1.5 , the valley of the $\mathrm{H}_{2} \mathrm{~S}$ curve increased and the peak of the iron sulfide curve decreased and became less noticeable. When the $\mathrm{O} / \mathrm{C}$ ratio is 1.8, the valleys and peaks of both $\mathrm{H}_{2} \mathrm{~S}$ and $\mathrm{FeS}_{\mathrm{x}}$ curves disappeared and $\mathrm{FeS}_{\mathrm{x}}$ generated a minimal amount at temperatures less than $900 \mathrm{~K}$. This is due to the weak reducibility of the atmosphere, which resulted in more $\mathrm{O}$ atoms in the system. The binding 
capacity of the $\mathrm{O}$ atom to the Fe element is greater than that of the $\mathrm{S}$ atom. In particular, Fe forms iron oxide or a copolymer with other oxides. From Figure 10b, as the reducing atmosphere is weakened, $\mathrm{SO}_{2}$ is generated at high temperatures with its content increasing as the $\mathrm{O} / \mathrm{C}$ ratio increases.

\subsubsection{Effect of Calcium/Sulfur Ratio on Sulfur Fixation}

Under a reducing atmosphere, a relatively high content of $\mathrm{CaO}$ in coal produces $\mathrm{CaS}$ as the intermediate product, which is conducive to $\mathrm{S}$ fixation. Low calorific value coal has high ash and aluminum silicon oxide content. $\mathrm{CaO}$ in coal ash mainly forms copolymer $\mathrm{CaO} \bullet \mathrm{xSiO}_{2} \bullet \mathrm{yAl}_{2} \mathrm{O}_{3}$ with $\mathrm{SiO}_{2}$ and $\mathrm{Al}_{2} \mathrm{O}_{3}$. The presence of $\mathrm{Fe}_{2} \mathrm{O}_{3}$ leaves $\mathrm{H}_{2} \mathrm{~S}$ at a lower level $[39,40]$. To separately investigate the effect of $\mathrm{CaCO}_{3}$ addition on the release of $\mathrm{H}_{2} \mathrm{~S}, \mathrm{Fe}_{2} \mathrm{O}_{3}, \mathrm{Al}_{2} \mathrm{O}_{3}$, and $\mathrm{SiO}_{2}$ are set to 0 mol. $\mathrm{Fe}_{2} \mathrm{O}_{3}$ does not inhibit the formation of $\mathrm{CaS}$. To study the relationship between $\mathrm{CaS}$ and the calcium to sulfur ratio, only $\mathrm{Al}_{2} \mathrm{O}_{3}$ and $\mathrm{SiO}_{2}$ are set to $0 \mathrm{~mol}$.

Using sample coal I as an example, the excess air ratio is set to 0.4 . Figures 11 and 12 show the curves of $\mathrm{H}_{2} \mathrm{~S}$ and $\mathrm{CaS}$ with the change of the calcium sulfur ratio, respectively, at different temperatures. With the increase of the calcium/sulfur ratio, $\mathrm{H}_{2} \mathrm{~S}$ rapidly decreased. When the calcium/sulfur ratio reached 1 to $1.2, \mathrm{H}_{2} \mathrm{~S}$ is almost fixated.

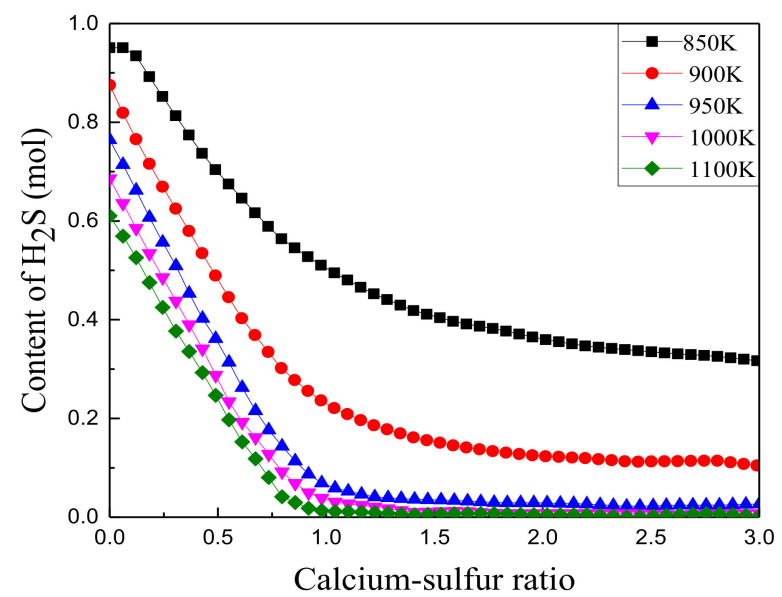

Figure 11. Balanced content of FeS.

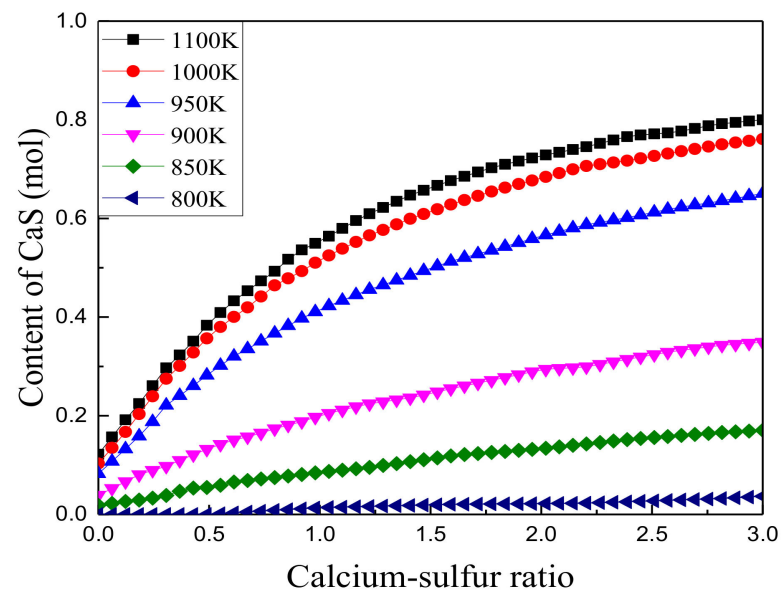

Figure 12. Balanced content of CaS.

Figure 12 demonstrate the large amount of $\mathrm{CaS}$ formed in a strong reducing atmosphere without the presence of large amounts of $\mathrm{Al}_{2} \mathrm{O}_{3}$ and $\mathrm{SiO}_{2}$. At around $800 \mathrm{~K}$, nearly no $\mathrm{CaS}$ is formed; however, as the temperature increased, $\mathrm{CaS}$ gradually increases, thereby producing a almost consistent curve at $1000 \mathrm{~K}$ or more. As the calcium/sulfur ratio increased, the increase of the $\mathrm{CaS}$ content became gradual. 
In combination with Figure 13, as the calcium/sulfur ratio increased, the combination of S, Fe, and Ca formed CaS through the endothermic reaction:

$$
\mathrm{FeS}_{\mathrm{x}}+\mathrm{CaCO}_{3} \rightarrow \mathrm{CaS}+\mathrm{FeO}+\mathrm{CO}_{2}
$$

The temperature rise also promotes this reaction. Therefore, at an equal calcium/sulfur ratio, the equilibrium content of $\mathrm{CaS}$ increases as the temperature increases.

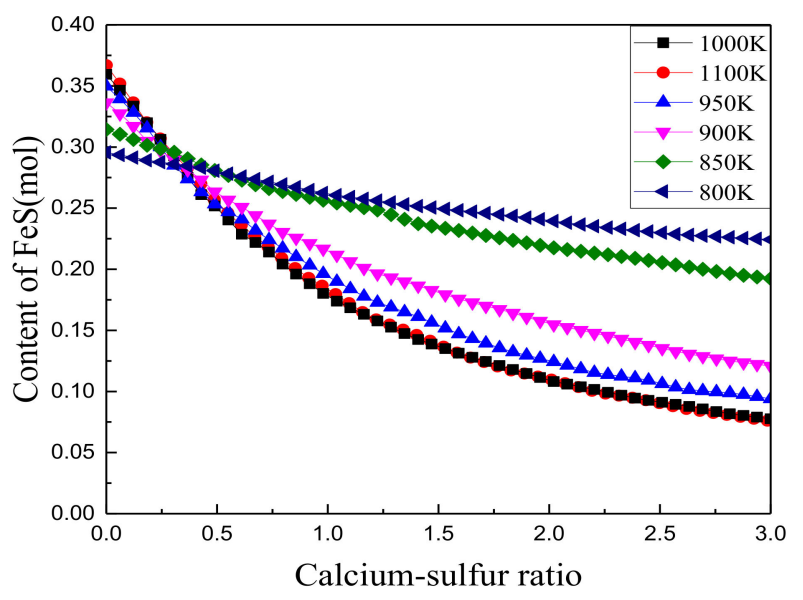

Figure 13. Balanced content of FeS.

\subsection{Analysis of Experimental Results}

The test data is plotted as a $\mathrm{SO}_{2}$ concentration (c)-time ( $\mathrm{t}$ ) curve in Figure 14. The area enclosed by the curve and the horizontal axis approximates the total amount of $\mathrm{SO}_{2}$ released during the experiment calculated as:

$$
m=\frac{\sum q_{v} * c_{i} * 10^{-6} * 1}{V_{m}} * M
$$

where $m$ is the mass of $\mathrm{SO}_{2}$ released $(\mathrm{mg}) ; q_{v}$ is the he total flow of gas $(19.67 \mathrm{~mL} / \mathrm{s}=1.18 \mathrm{~L} / \mathrm{min}) ; c_{i}$ is the $\mathrm{SO}_{2}$ concentration at time $i(\mathrm{ppm})$, corresponding to the area of the column at time $i$ in Figure 13; $V_{m}$ is the molar volume at the ambient temperature $(298 \mathrm{~K})(24.45 \mathrm{~L} / \mathrm{mol})$; and $\mathrm{M}$ is the molar mass of $\mathrm{SO}_{2},(64 \mathrm{~g} / \mathrm{mol})$.

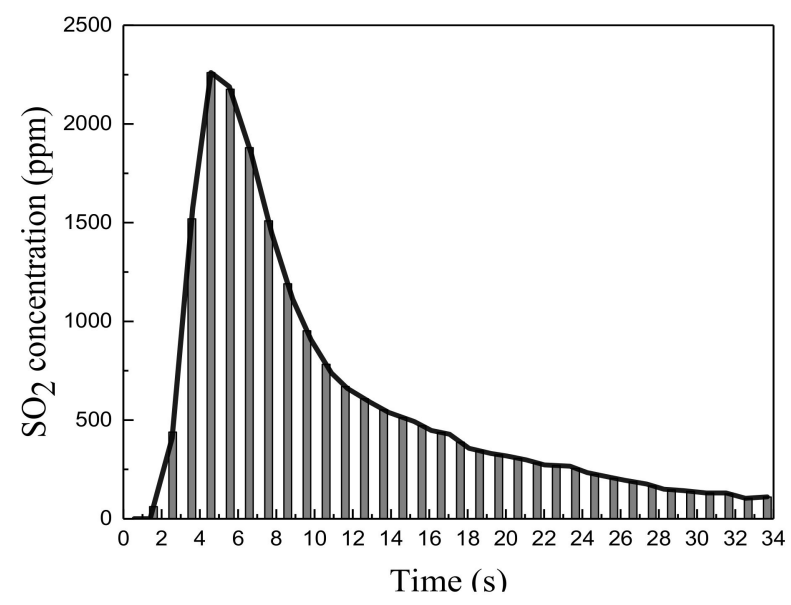

Figure 14. Curve of $\mathrm{SO}_{2}$ release concentration.

Three kinds of $100 \mathrm{mg}$ coal samples were made to completely undergo a reaction at $1000{ }^{\circ} \mathrm{C}$ to obtain a $\mathrm{SO}_{2}$ release curve. Each coal sample was subjected to three experiments and the results were 
averaged to obtain the total amount of $\mathrm{SO}_{2}$ released from the coal sample. The total $\mathrm{SO}_{2}$ emissions and sulfur fixation rate were calculated from the $100 \mathrm{mg}$ test material, and the total sulfur content St was determined, as shown in Table 6.

Comparing Table 4 with Table 6, a consistent sulfur fixation law, i.e., sample coal I > sample coal II $>$ middling, is observed, as shown in Figure 15. According to Table 2, the alkaline oxide/sulfur ratio is in the order of sample coal I > sample coal II > middling. The relative amount of alkaline oxide and sulfur in coal ash determines its sulfur fixation ability. However, a certain deviation between the simulation and the experimental results is observed, due to experimental limitations where the cycle process cannot be completed as the $\mathrm{SO}_{2}$ generated from the combustion of coal sample incompletely reacts with sufficient coal ash. A considerable amount of $\mathrm{SO}_{2}$ was not fixed as it entered and escaped the pipeline at the end of the reactor.

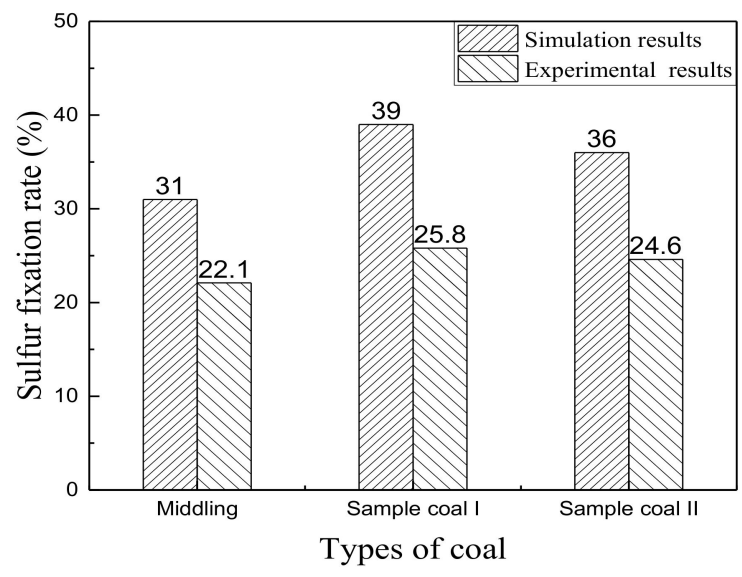

Figure 15. Comparison of sulfur fixation results.

Table 6. Experimental sulfur fixation rate.

\begin{tabular}{ccccc}
\hline & Unit & Middling & Sample Coal I & Sample Coal II \\
\hline Actual release & $\mathrm{mg}$ & 2.18 & 2.73 & 2.61 \\
Total sulfur & $\%$ & 1.40 & 1.84 & 1.5 \\
Total S release & $\mathrm{mg}$ & 2.80 & 3.68 & 3.46 \\
Sulfur fixation rate & $\%$ & 22.1 & 25.8 & 24.6 \\
\hline
\end{tabular}

\subsection{Literature Verification of Simulation Results}

According to a test report of coal combustion characteristics of a circulating fluidized bed boiler for a $2 \times 660 \mathrm{MW}_{\mathrm{e}}$ unit in a Shanxi low-calorific coal power generation project, the middling and gangue used in the report and the mixed coal burned from the design experimental bench are from the same origin, the blending ratio is similar, and the combustion temperature is close, so the results are comparable. Test coal I and II were, respectively, blended with middling and gangue at a ratio of 77:23 and 6:4. In this report, the researchers tested the self-desulfurization performance of coal samples and the results are shown in Table 7.

Table 7. Report test sulfur fixation rate.

\begin{tabular}{cccc}
\hline & Unit & Sample Coal I & Sample Coal II \\
\hline Total sulfur & $\%$ & 1.85 & 1.72 \\
Test temperature range & $\mathrm{K}$ & $1180-1210$ & $1110-1200$ \\
Sulfur fixation rate & $\%$ & 35 & $20.4-31.6$ \\
\hline
\end{tabular}

Comparing Tables 4 and 6, when considering mixed coal, the simulation and experimental results are also consistent with the literature results, that is, the sulfur fixation rate: Coal I > coal II. This is 
consistent with the order of the sulfur-fixing law: The relative amount of alkaline oxides and sulfur in the coal ash determines the sulfur-fixing capacity of the coal ash.

While the simulation results cannot accurately calculate the specific content of the sulfur-containing phase, it can characterize the relative amount of each sulfur-containing phase and the change trend under different conditions.

\subsection{Experimental Analysis Based on $3 \mathrm{MW}_{\text {th }}$ Test Bench}

The test coal was tested under various operating conditions and parameters. The combustion efficiency without limestone desulfurization was $92.99 \%$ to $94.80 \%$, as shown in Table 8 . When the test coal is not cast with limestone at an oxygen content of 3-6\%, the $\mathrm{SO}_{2}$ emission increased with the increase of the bed temperature and the self-desulfurization efficiency gradually decreased, as shown in Figure 16. This is attributed to the bed temperature rise, which resulted in the decomposition of the sulfate accumulated in the bed material (including large amount of circulating ash) in the furnace, thereby increasing the mass concentration of $\mathrm{SO}_{2}$ emissions in a short period. However, the limited desulfurization components in coal leads to an increase in the mass concentration of $\mathrm{SO}_{2}$ emissions.

Therefore, there is an optimal desulfurization reaction temperature for limestone desulfurization in CFB boilers. The continuous increase of bed temperature accelerated the thermal decomposition rate of sulfate and $\mathrm{CaSO}_{4}$ produced during the desulfurization reaction, increased the proportion of generated $\mathrm{SO}_{2}$, and reduced the desulfurization efficiency in the furnace.

Table 9 shows the desulfurization conditions under the limestone test conditions, which are consistent with those of the calculation results of thermal equilibrium. With the increase of the $\mathrm{Ca} / \mathrm{S}$ molar ratio, the desulfurization efficiency gradually increased, resulting in a better sulfur fixation effect. However, due to the addition of limestone, the total amount of ash and slag increased, resulting in the incomplete combustion loss of solids and low combustion efficiency.

Table 8. Combustion data of desulfurization conditions without limestone.

\begin{tabular}{|c|c|c|c|c|c|c|}
\hline $\begin{array}{c}\text { Serial } \\
\text { Number }\end{array}$ & Item & Unit & $\begin{array}{c}\text { Working } \\
\text { Condition } 1\end{array}$ & $\begin{array}{c}\text { Working } \\
\text { Condition } 2\end{array}$ & $\begin{array}{c}\text { Working } \\
\text { Condition } 3\end{array}$ & $\begin{array}{c}\text { Working } \\
\text { Condition } 4\end{array}$ \\
\hline 1 & Thermal power & MW & 2.27 & 2.84 & 2.99 & 1.01 \\
\hline 2 & Amount of limestone & $\mathrm{kg} / \mathrm{h}$ & 0 & 0 & 0 & 0 \\
\hline 3 & Calcium-sulfur molar ratio & - & 0 & 0 & 0 & 0 \\
\hline 4 & Bed temperature & K & 1140 & 1174 & 1197 & 1058 \\
\hline 5 & Excess air factor $(\alpha)$ & - & 1.35 & 1.22 & 1.2 & 2.01 \\
\hline 6 & Bottom ash share $(\alpha \mathrm{lz})$ & $\%$ & 71.8 & 71.8 & 71.8 & 71.8 \\
\hline 7 & Bottom ash carbon content $(\mathrm{Clz})$ & $\%$ & 1.94 & 4.22 & 3.26 & 1.39 \\
\hline 8 & Fly ash share ( $\alpha \mathrm{fh})$ & $\%$ & 28.2 & 28.2 & 28.2 & 28.2 \\
\hline 9 & Carbon content of fly ash (Cfh) & $\%$ & 10.36 & 8.27 & 7.31 & 9.93 \\
\hline 10 & Combustion efficiency ( $\eta \mathrm{r}$ ) & $\%$ & 94.32 & 92.99 & 94.34 & 94.8 \\
\hline 11 & Desulfurization efficiency ( $\eta \mathrm{s})$ & $\%$ & 31.6 & 26.4 & 20.3 & 38 \\
\hline
\end{tabular}

Table 9. Desulfurization efficiency under test conditions with limestone.

\begin{tabular}{ccccccccc}
\hline Item & Unit & $\mathbf{5}$ & $\mathbf{6}$ & $\mathbf{7}$ & $\mathbf{8}$ & $\mathbf{9}$ & $\mathbf{1 0}$ & $\mathbf{1 1}$ \\
\hline Thermal power & $\mathrm{MW}$ & 2.58 & 2.58 & 2.58 & 2.58 & 2.58 & 2.58 & 2.58 \\
Amount of limestone & $\mathrm{kg} / \mathrm{h}$ & 177.5 & 177.5 & 177.5 & 177.5 & 177.5 & 256.9 & 174.3 \\
Ca/S & - & 3.7 & 3.7 & 3.7 & 3.7 & 3.7 & 5.36 & 3.64 \\
Bed temperature & $\mathrm{K}$ & 1166 & 1159 & 1119 & 1172 & 1176 & 1158 & 1152 \\
Excess air factor $(\alpha)$ & - & 1.22 & 1.21 & 1.22 & 1.22 & 1.24 & 1.2 & 1.21 \\
Bottom ash share $(\alpha \mathrm{lz})$ & $\%$ & 71 & 71 & 71 & 71 & 71 & 71 & 71 \\
Bottom ash carbon content $(\mathrm{Clz})$ & $\%$ & 3.4 & 4.06 & 2.73 & 4.33 & 3.07 & 4.88 & 2.6 \\
Fly ash share $(\alpha \mathrm{fh})$ & $\%$ & 29 & 29 & 29 & 29 & 29 & 29 & 29 \\
Carbon content of fly ash $(\mathrm{Cfh})$ & $\%$ & 5.68 & 7.14 & 7.54 & 6.09 & 4.74 & 5.32 & 9.93 \\
Combustion efficiency $(\eta \mathrm{r})$ & $\%$ & 93 & 91.39 & 92.9 & 91.63 & 93.94 & 90.46 & 91.83 \\
Desulfurization efficiency $(\eta \mathrm{s})$ & $\%$ & 94.3 & 94.19 & 88.55 & 88.24 & 88.88 & 96.51 & 88.34 \\
\hline
\end{tabular}




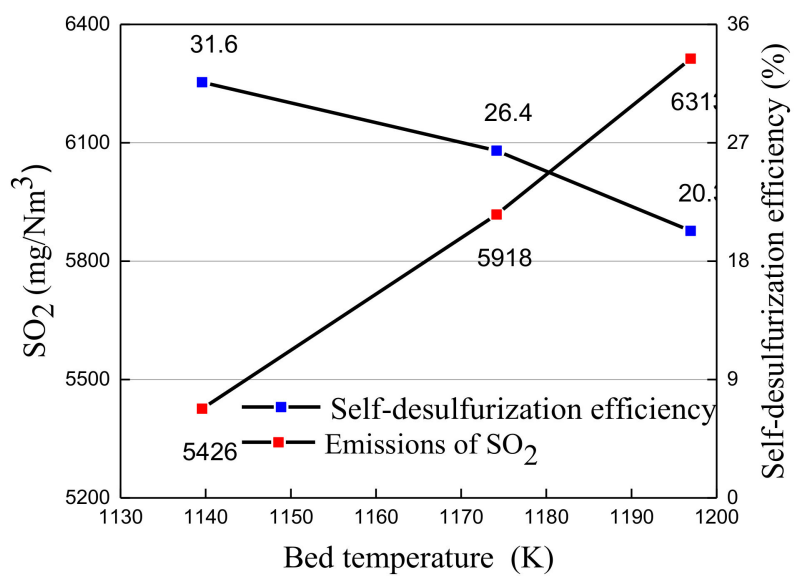

Figure 16. Relationship between $\mathrm{SO}_{2}$ emission and self-desulfurization efficiency with bed temperature.

Under a load of $2.58 \mathrm{MW}_{\text {th }}$, the calcium/sulfur molar ratio is 3.7, the bed temperature is $900{ }^{\circ} \mathrm{C}$, the primary air ratio is approximately $40 \%$, and the secondary air ratio is unchanged. Figure 17 shows the influence of the oxygen volume fraction at the furnace outlet on the $\mathrm{SO}_{2}$ emission mass concentration. The changes in $\mathrm{SO}_{2}$ emission mass concentration with the increase of oxygen volume fraction is not very evident.

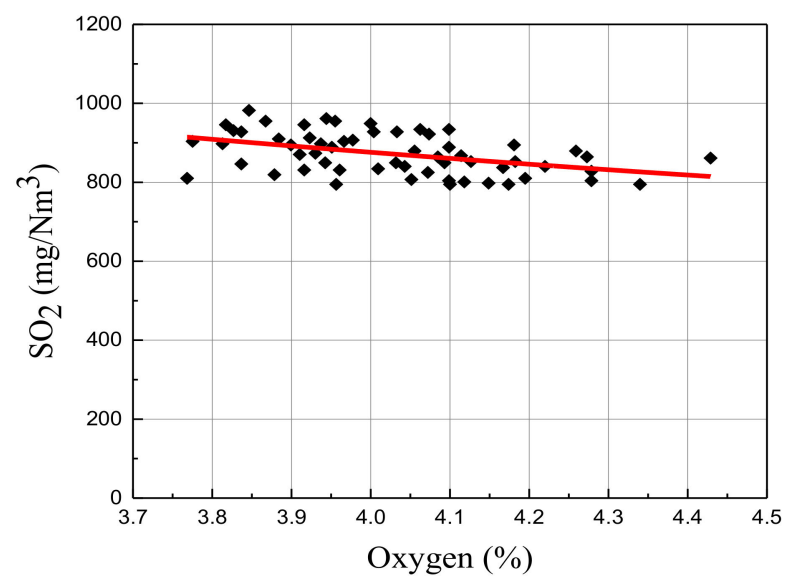

Figure 17. Sulfur dioxide emission in relation with the amount of oxygen.

\section{Conclusions}

Through thermodynamic equilibrium simulation of an oxidizing atmosphere, $\mathrm{S}$ in mixed coal samples of middling and gangue is mainly converted to $\mathrm{SO}_{2}$ and alkali metal sulfate. When the temperature is less than $1000 \mathrm{~K}$ in a reducing atmosphere, the middling is mainly composed of gas-phase $\mathrm{H}_{2} \mathrm{~S}$ and small amounts of COS. A small amount of solid sulfur compounds appeared in the mixed coal with gangue, with the main components being $\mathrm{Fe}_{0.877} \mathrm{~S}$ and $\mathrm{FeS}$.

During the combustion of mixed coal samples using simulation, $\mathrm{O} / \mathrm{C}$ ratio established more accurate characterization of atmospheric reducibility than the excess air coefficient. As the $\mathrm{O} / \mathrm{C}$ ratio increased, the distribution curves of the sulfur-containing substances shift to lower temperatures. At an $\mathrm{O} / \mathrm{C}$ ratio of 1.8 , the valley of the $\mathrm{H}_{2} \mathrm{~S}$ curve disappeared with nearly zero iron sulfide content.

The small-scale experimental bench showed simulation results consistent with the sulfur-fixing, i.e., sample coal I > sample coal II > middling. This analysis showed that the sulfur-fixing capacity of coal ash depends on its relative amount of alkaline oxide and sulfur.

The $3 \mathrm{MW}_{\text {th }}$ test bench test showed high self-desulfurization efficiency of up to $31.6 \%$ of the sample coals at a temperature range of 1130 to $1173 \mathrm{~K}$. The mass concentration of $\mathrm{SO}_{2}$ emission was obtained as approximately $800-1000 \mathrm{mg} / \mathrm{Nm}^{3}$. 
Author Contributions: Conceptualization, formal analysis, methodology, validation, writing-original draft preparation, L.Z.; Conceptualization, methodology, software, writing-review and editing, Y.D.; Supervision and review, Z.K. and B.S.; Data curation, review, Y.Z. All authors have read and agreed to the published version of the manuscript.

Funding: This research received no external funding.

Conflicts of Interest: The authors declare no conflict of interest.

\section{References}

1. Ren, A.P. The Planning of Low Calorific Value Coal Source in Shanxi Province and Its Influence on Shanxi Power Grid. Shanxi Electr. Power 2015, 47, 47-49.

2. Wang, X.L. Research on comprehensive power generation utilization of energy-saving technology application for low calorific value coal based upon the low calorific value coal power generation project in Yonglong mining area. China Coal 2019, 45, 82-86.

3. Li, C.; Zhao, L.; Ren, Q. Status analysis and development discussion of coal gangue comprehensive utilization. Environ. Dev. 2015, 27, 72-74.

4. Liang, Y.S. Study on Present Situation and Progress of Coal Gangue Resource Utilization. Energy Energy Conserv. 2019, 72, 72-73.

5. Tan, Q.Y.; Peng, F.; Peng, H.W.; Tang, X.S. Optimization Design of Two-Stage Desulfurization System for CFB Boilers. Electr. Power Constr. 2014, 35, 89-94.

6. Jin, D.P.; Wang, M.Y.; Song, W.X. Research on Deep Desulfurization Process of CFB Boiler Tail Humidification and Activation. Power Syst. Eng. 2014, 30, 41-43.

7. Weng, A.X.; Zhou, H.; Wang, Z.H.; Chi, Z.H.; Jiang, X.; Cen, K.F. Experimental Study on Formation of $\mathrm{SO}_{2}$ of Blending Coal Combustion in High Temperature. Boil. Technol. 2003, 34, 1-4.

8. Yu, J.L.; Lucas, J.; Wall, T.; Liu, G.; Sheng, C.D. Modeling the development of char structure during the rapid heating of pulverized coal. Combust. Flame 2004, 136, 519-532. [CrossRef]

9. Engin, B.; Atakul, H.; Unlu, A.; Olgun, Z. CFB combustion of low-grade lignites: Operating stability and emissions. J. Energy Inst. 2019, 92, 542-553. [CrossRef]

10. Li, J.Y.; Wang, J.M. Comprehensive utilization and environmental risks of coal gangue: A review. J. Clean. Prod. 2019, 239, 117946. [CrossRef]

11. Yrjas, P.; Iisa, K.; Hupa, M. Comparison of $\mathrm{SO}_{2}$ capture capacities of limestones and dolomites under pressure. Fuel 1995, 74, 359-400. [CrossRef]

12. Dong, X.W.; Wang, H.; Liu, H.; Qin, J.R. Study on $\mathrm{SO}_{2}$ emission under various atmospheres during coal combustion. Acta Sci. Circumstantiae 2003, 23, 322-326.

13. Shi, Y.; Zhong, W.Q.; Shao, Y.J.; Liu, X.J. Energy efficiency analysis of pressurized oxy-coal combustion system utilizing circulating fluidized bed. Appl. Therm. Eng. 2019, 150, 1104-1115. [CrossRef]

14. Li, S.Y.; Li, W.; Xu, M.X.; Wang, X.; Li, H.Y.; Lu, Q.G. The experimental study on nitrogen oxides and $\mathrm{SO}_{2}$ emission for oxy-fuel circulation fluidized bed combustion with high oxygen concentration. Fuel 2015, 146, 81-87. [CrossRef]

15. Jia, L.; Tan, Y.; McCalden, D.; Wu, Y.; He, I.; Symonds, R.; Anthony, E.J. Commissioning of a 0.8 $\mathrm{MW}_{\text {th }} \mathrm{CFBC}$ for oxy-fuel combustion. Int. J. Greenh. Gas Control 2012, 7, 59-69. [CrossRef]

16. Jia, L.; Tan, Y.; Anthony, E.J. Emissions of $\mathrm{SO}_{2}$ and $\mathrm{NO}_{\mathrm{x}}$ during Oxy-Fuel CFB Combustion Tests in a Mini-Circulating Fluidized Bed Combustion Reactor. Energy Fuels 2010, 24, 910-915. [CrossRef]

17. Lyngfelt, A.; Leckner, B. Sulphur capture in fluidized bed boilers: The effect of reductive decomposition of $\mathrm{CaSO}_{4}$. Chem. Eng. Sci. 1989, 40, 1131-1141. [CrossRef]

18. Belin, E. Babcock \& Wilcox CFB boilers-Design and experience. Fuel Energy Abstr. 2002, 43, 272.

19. Liu, D.B.; Li, W.; Li, S.Y.; Song, W.H.; Liu, D.F.; Kong, R.J. Transformation characteristics of sodium, chlorine and sulfur of Zhundong coal during $\mathrm{O}_{2} / \mathrm{CO}_{2}$ combustion in circulating fluidized bed. Energy 2019, 185, 254-261. [CrossRef]

20. Chen, G.B.; Chatelier, S.; Lin, H.T.; Wu, F.H.; Lin, T.H. A Study of Sewage Sludge Co-Combustion with Australian Black Coal and Shiitake Substrate. Energies 2018, 11, 3436. [CrossRef]

21. Wang, H.; Zhang, L.Z.; Qin, J.R.; Zheng, C.G. Experimental study on the desulfurization of calcium-based sorbent in $\mathrm{CO}_{2}$ enriched environment. J. Eng. Thermophys. 2001, 22, 374-377. 
22. Wang, H.; Zhang, L.Z.; Lu, X.H.; Zhen, C.G. Microstructure changes of calcium-based sorbent during desulfurization in $\mathrm{O}_{2} / \mathrm{CO}_{2}$ mixture. J. Eng. Thermophys. 2001, 22, 127-129.

23. Wang, H.; Qiu, J.R.; Zheng, C.G. $\mathrm{SO}_{2}$ formation characteristics of coal in $\mathrm{O}_{2} / \mathrm{CO}_{2}$ mixture. J. Huazhong Univ. Sci. Technol. 2002, 30, 100-102.

24. Zhang, Z.L.; Zeng, Q.D. Numerical simulation and experimental analysis on nitrogen and sulfur oxides emissions during the co-combustion of Longyan anthracite and sawmill sludge. Fuel 2019, 254, 115611. [CrossRef]

25. Yang, N.N.; Guo, H.Q.; Liu, F.R.; Zhang, H.; Hu, Y.F.; Hu, R.S. Effects of atmospheres on sulfur release and its transformation behavior during coal thermolysis. Fuel 2018, 215, 446-453. [CrossRef]

26. Hou, J.L.; Ma, Y.; Li, S.Y.; Shi, J.; He, L.; Li, J. Transformation of sulfur and nitrogen during Shenmu coal pyrolysis. Fuel 2018, 231, 134-144. [CrossRef]

27. Wang, H.Y.; Cheng, C.F.; Chen, C. Characteristics of polycyclic aromatic hydrocarbon release during spontaneous combustion of coal and gangue in the same coal seam. J. Loss Prev. Process Ind. 2018, 55, 392-399. [CrossRef]

28. Liang, X.; Wang, Q.; Luo, Z.; Eddings, E.; Ring, T.; Li, S.; Lin, J.; Xue, S.; Han, L.; Xie, G. Experimental and numerical investigation on sulfur transformation in pressurized oxy-fuel combustion of pulverized coal. Appl. Energy 2019, 253, 113542. [CrossRef]

29. Xu, L.J.; Cheng, L.M.; Ji, J.Q.; Wang, Q.H.; Fang, M.X. A comprehensive CFD combustion model for supercritical CFB boilers. Particuology 2019, 43, 29-37. [CrossRef]

30. Xiao, P.; Sun, X.B.; Xu, Z.Q. Test and study on selfdesulfuration behavior of coal sorts in $1 \mathrm{MW}_{\text {th }} \mathrm{CFB}$ combustion test stand. Therm. Power Gener. 2004, 42, 30-33.

31. Lu, Q.G.; Yong, Y.M.; Na, Y.J.; Bao, S.L.; Sun, Y.K.; He, J.; Jiao, W.H.; Gao, M. Influence of coal on $\mathrm{SO}_{2}$ and $\mathrm{NO}_{x}$ emissions of circulating fluidized bed combustion. Proc. CSEE 2005, 25, 145-149.

32. Zhao, P.B.; Wang, P.L.; Wang, H.T.; Liu, K.F.; Han, Y. Desulfuration efficiency Test and Study on Different Particle Size. Inn. Mong. Electr. Power 2010, 28, 24-26.

33. Adanez, J.; Gayán, P.; Grasa, G.; Diego, L.F.D.; Armesto, L.; Cabanillas, A. Circulating fluidized bed combustion in the turbulent regime: Modelling of carbon combustion efficiency and sulphur retention. Fuel 2001, 80, 1405-1414. [CrossRef]

34. Niu, S.L.; Han, K.H.; Lu, C.M. Release of sulfur dioxide and nitric oxide and characteristic of coal combustion under the effect of calcium based organic compounds. Chem. Eng. J. 2011, 168, 255-261. [CrossRef]

35. Hlincik, T.; Buryan, P. Desulfurization of boiler flue gas by means of activated calcium oxide. Fuel Process. Technol. 2013, 111, 62-67. [CrossRef]

36. Shao, L.M.; Fan, S.S.; Zhang, H.; Yao, Q.S.; He, P.J. $\mathrm{SO}_{2}$ and $\mathrm{NO}_{\mathrm{x}}$ emissions from sludge combustion in a $\mathrm{CO}_{2} / \mathrm{O}_{2}$ atmosphere. Fuel 2013, 109, 178-183. [CrossRef]

37. Ma, L.; Guo, A.L.; Fang, Q.Y.; Wang, T.X.; Zhang, C.; Chen, G. Combustion interactions of blended coals in an $\mathrm{O}_{2} / \mathrm{CO}_{2}$ mixture in a drop tube furnace: Experimental investigation and numerical simulation. Appl. Therm. Eng. 2018, 145, 184-200. [CrossRef]

38. Yan, J.; Lu, X.; Wang, Q.; Kang, Y.; Li, J.; Xu, Z.; Lei, X.; Zheng, X.; Fan, X.; Liu, Z. Study on the influence of secondary air on the distributions of flue gas composition at the lower part of a $600 \mathrm{MW}$ supercritical CFB boiler. Fuel Process. Technol. 2019, 196, 106035. [CrossRef]

39. Yang, T.H.; Zhou, J.H.; Li, R.D.; Cen, K.F. Kinetics for formation of CaS as sulphur intermediate retention. Proc. CSEE 2006, 26, 104-108.

40. Duan, Y.Q.; Duan, L.B.; Anthony, E.J.; Zhao, C.S. Nitrogen and sulfur conversion during pressurized pyrolysis under $\mathrm{CO}_{2}$ atmosphere in fluidized bed. Fuel 2017, 189, 98-106. [CrossRef]

(C) 2020 by the authors. Licensee MDPI, Basel, Switzerland. This article is an open access article distributed under the terms and conditions of the Creative Commons Attribution (CC BY) license (http://creativecommons.org/licenses/by/4.0/). 